\title{
NOVITATES GABONENSES 61. A NEW RARE ENDEMIC CALVOA (MELASTOMATACEAE) FROM MBE NATIONAL PARK, GABON
}

\author{
MIGUEL E. LEAL \\ Missouri Botanical Garden, P.O. Box 299, St. Louis, Missouri 63166, USA \\ e-mail: Miguel.Leal@mobot.org
}

\begin{abstract}
SUMMARY
A new species of Calvoa from the Mbe National Park, Monts de Cristal is described.
\end{abstract}

Key words: Calvoa, Melastomataceae, Africa, Gabon, taxonomy.

In August 2004, during the delimitation of the southern part of the Mbe National Park in the Monts de Cristal on the summit of a table mountain, a hairy species of Calvoa with white-spotted leaves was encountered. Such distinctive individuals were not described in the regional floras (Jacques-Félix, 1983a, b), the recent checklist of the Melastomataceae (Parmentier \& Geernik, 2003), nor in the recent revision of the genus (Figueiredo, 2001). This new species is obviously distinctive from all the other Calvoa species by the white spots on its leaves; hence its name maculata. In its hairiness it is closest to $C$. hirsuta Hook.f., but in its heart-shaped leaves closest to $C$. pulcherrima Gilg ex Engl. The distribution of the new species is exclusively restricted to a table mountain called Mont Mbilan Plateau.

Calvoa maculata M.E. Leal, spec. nov. - Fig. 1

Haec species pulcher ab Calvoa hirsuta differt foliis leucomaculatis etiam lobi coronans capsulam frimbriati sunt. - Typus: M.E. Leal 212 (holo MO; iso LBV, WAG), Gabon, Monts de Cristal, 24 August 2004.

Small herb, 2-3 cm high, terrestrial, dark green, hirsute with $1 \mathrm{~mm}$ long white hairs; branches slightly angular. Petiole 7-10 mm. Lamina ovate truncate to cuneate, 1.1-2 $(-3.8)$ by $1.5-2.5 \mathrm{~cm}$, margin serrulate ciliate, apex acute, three main veins, sparse slender hairs surrounded by a white dot $(0.2 \mathrm{~mm}$ diameter $)$ above, below whitish green with hairs on the veins. Inflorescence a terminal single-branched cyme, sessile or with a $0.5 \mathrm{~cm}$ long peduncle, with 1-6 sessile flowers. Hypanthium 1.5-2.5 mm long, densely hirsute. Calyx lobes $1.5-2$ by $0.1-0.3 \mathrm{~mm}$ triangular with a truncate apex. Petals $4-5$ by 3-4 $\mathrm{mm}$ white. Anthers $1 \mathrm{~mm}$ long. Style 1-2 $\mathrm{mm}$ long, stigma capitate. Capsule 3-4 by 5-6 $\mathrm{mm}$ hirsute; with a 5-lobed crown exerted for $1.5 \mathrm{~mm}$ and frimbricate. Seeds $0.5 \mathrm{~mm}$. 


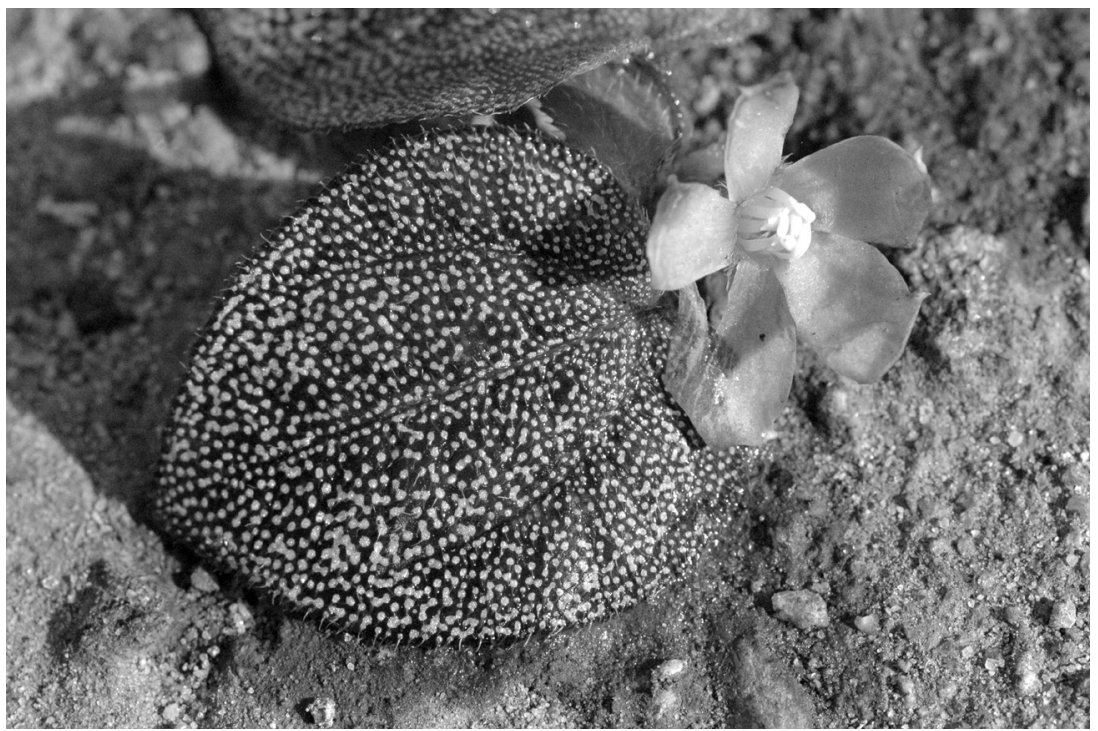

Calvoa maculata M.E. Leal (M.E. Leal 212, MO).

Distribution - Gabon, Monts de Cristal, Mont Mbilan Plateau, 0 51' 4" N, $10^{\circ} 26^{\prime} 0^{\prime \prime} \mathrm{E}$.

Habitat - Terrestrial on forest floor of semi-elfin cloud forest; altitude 500-700 m.

Notes - Some Calvoa species are very rare, known from one locality by a few specimens and not recorded since, e.g., C. leonardii and C. stenophylla (Figueiredo, 2001). This new species $C$. maculata is probably also going to remain rare, as this is a small population isolated on a mountain top. Its rareness has implications for conservation. The plateau is situated partially in the Mbe National Park, but there is economical pressure to exploit the area for iron. Such activities will lead to its extinction. Calvoa maculata is not the only rare endemic taxon in this part of the Monts de Cristal. The high number of endemic taxa was a reason to conserve this area as a national park.

The reason why there are so many endemic taxa in the Monts de Cristal has to do with forest history. The Monts de Cristal is considered a former forest refugium, an area where the forest persisted during the Last Glacial Maximum, 18,000 years ago, when due to a drier climate much of the rain forest had disappeared (Maley, 1989). Forest refugia are characteristically rich in slowly dispersing species (Sosef, 1994; Leal, 2004) and this is confirmed by botanical data from mega-transects $(50 \mathrm{~km}<)$ through the Monts de Cristal (Leal et al., in prep.). This new Calvoa species is another indication how botanically rich and valuable the area is.

\section{ACKNOWLEDGEMENTS}

Fieldwork was funded by the National Geographical Society and the Central Africa Regional Program of the Environment (CARPE) in collaboration with the Wildlife Conservation Society (WCS). The author was grateful for the comments of E. Figueiredo, specialist in the genus. 


\section{REFERENCES}

Figueiredo, E. 2001. A revision of Calvoa Hook.f. (Melastomataceae). Bot. J. Linn. Soc. 136: $179-205$.

Jacques-Félix, H. 1983a. Mélastomatacées. Flore du Cameroun 24: 80-91.

Jacques-Félix, H. 1983b. Mélastomatacées. Flore du Gabon 25: 58-70.

Leal, M.E. 2004. The African rain forest during the Last Glacial Maximum, an archipelago of forests in a sea of grass. PhD thesis. Propress Wageningen.

Maley, J. 1989. Late Quaternary climatic changes in the African rain forest: the question of forest refuges and the major role of sea surface temperature variations. In: M. Leinen \& M. Sarnthein (eds.), Paleoclimatology and Paleometeorology: modern and past patterns of global atmospheric transport. NATO Adv. Sci. Inst. Ser. C. Math. \& Phys. Sci. 282: 585-616.

Parmentier, I. \& D. Geernik. 2003. Checklist of the Melastomataceae of Equatorial Guinea. Anales Jard. Bot. Madrid 60: 331-346.

Sosef, M.S.M. 1994. Refuge begonias. Taxonomy, phylogeny and historical biogeography of the Begonia sect. Loasibegonia and sect. Scutobegonia in relation to glacial rain forest refuges in Africa. Agric. Univ. Wageningen Pap. 94: 1-306. 